\title{
DRAWBAR PARAMETERS OF TRACTOR WITH PROTOTYPES OF DRIVING WHEELS AND STANDARD TYRES
}

\author{
Radoslav MAJDAN, Rudolf ABRAHÁM* , Zdenko TKÁČ, Miroslav MOJŽıŠ \\ Slovak University of Agriculture in Nitra, Slovak Republic
}

\begin{abstract}
The paper presents the main drawbar parameters of tractor (drawbar pull, drawbar power and wheels slip) operating in a grass plot and evaluates the utilization of specially modified tyres with spikes. These prototypes of driving wheels were designed at the Department of Transport and Handling of the Slovak University of Agriculture in Nitra. The designed mechanism with spikes is mounted on standard tractor tyres, in which grooves were made. Spikes are hidden in grooves during transportation on a route. On the grassy landscape or soil, the spikes are ejected in order to improve the drawbar parameters. During operation, the drawbar pull and the rotation speeds of wheels were measured, whereupon the wheel slip was calculated. Results show the highest increase in tractor speed at the second gear and high load in utilized prototypes of the driving wheels $\left(1.89 \mathrm{~km} \cdot \mathrm{h}^{-1}\right)$ in comparison to standard tyres $\left(1.10 \mathrm{~km} \cdot \mathrm{h}^{-1}\right)$. Measurements also demonstrate the highest improvement of drawbar power under the aforementioned conditions in case of tractor with prototypes of driving wheels $(1,719.87 \mathrm{~W})$ in comparison with tractor using the standard tyres $(1,061.57 \mathrm{~W})$.
\end{abstract}

Keywords: wheels slip; drawbar pull; tractor power; loss of energy

The paper presents a comparison of tyre slip for two types of wheels. A special mechanical system modifying standard tyres was mounted on the tractor wheels. Grooves were made on standard tyres to which a special mechanism with metal nibs was inserted. Designed tyre modifications are characteristic by simple mounting on tyres and a possibility of transportation on metalled road without a risk of their deterioration. Traction performance of the modified tyres was compared with traction performance of standard tyres. Tests under operational conditions were realized on a grass plot; a tractor with an engine power of $12 \mathrm{~kW}$ was used for an experimental measurement of traction performance. Another tractor loaded the tractor during the measurement.

The testing of new tractor designs in agriculture becomes more and more popular since these machines directly influence the agricultural production results (Hujo et al., 2012; Tulík et al., 2013). The increase of tractor travelling speed resulting from the reduction of drive wheels slip and subsequent reduction of wheel to soil impact time is one of possible negative effects of suppression of soil compaction by tractor. Knowledge on soil compaction has been significantly furthered in the last three decades, particularly after the publishing of results of an international project in the form of more than twenty papers related to experimental soil compaction in North America and Europe. These research works have proven the following facts (Duiker, 2004):

1. topsoil compaction is caused by surface contact pressure;

2. upper part of subsoil compaction is caused by surface contact pressure and axle load;

3. deeper subsoil compaction is caused only by axle load.
These facts confirm the measurements of soil compaction in various depths depending on different soil moistures (Malý et al., 2015; Malý and Kučera, 2014).

Drawbar performance influences the soil compaction (Rataj et al., 2009; Rataj et al., 2016) as the soil is less compacted at lower slip and higher speed causes lower soil compaction.

Nowadays, diesel oil and petrol products belong to the most utilized fuels. Unfortunately, fossil fuels are nonrenewable and exhaustible sources of energy (Uhrinová et al., 2011a; Uhrinová et al. 2011b). The increasing of tractor traction performance influences the fuel consumption and emissions of exhaust gases. Lower wheel slip and higher traction performance have also impacts on multiple tractor parameters (Kosiba et al., 2010).

\section{Material and methods}

\section{Measurement system}

Drawbar pull measurement of the tractor type Mini 070 (Agrozet, Czech Republic) equipped with different types of wheels (Fig. 1) was performed by means of a tensiometric force sensor marked as 150 EMS, as shown in Fig. 2.

The description of HMG 3010 is presented in work published by Müllerová et al. (2012). The technical parameters and specification of the tractor Mini 070 equipped with different wheel types and the tractor TZ-4K14 used for loading (braking) of the first one is presented by Abrahám et al. (2015). Four-wheel drive loading tractor 


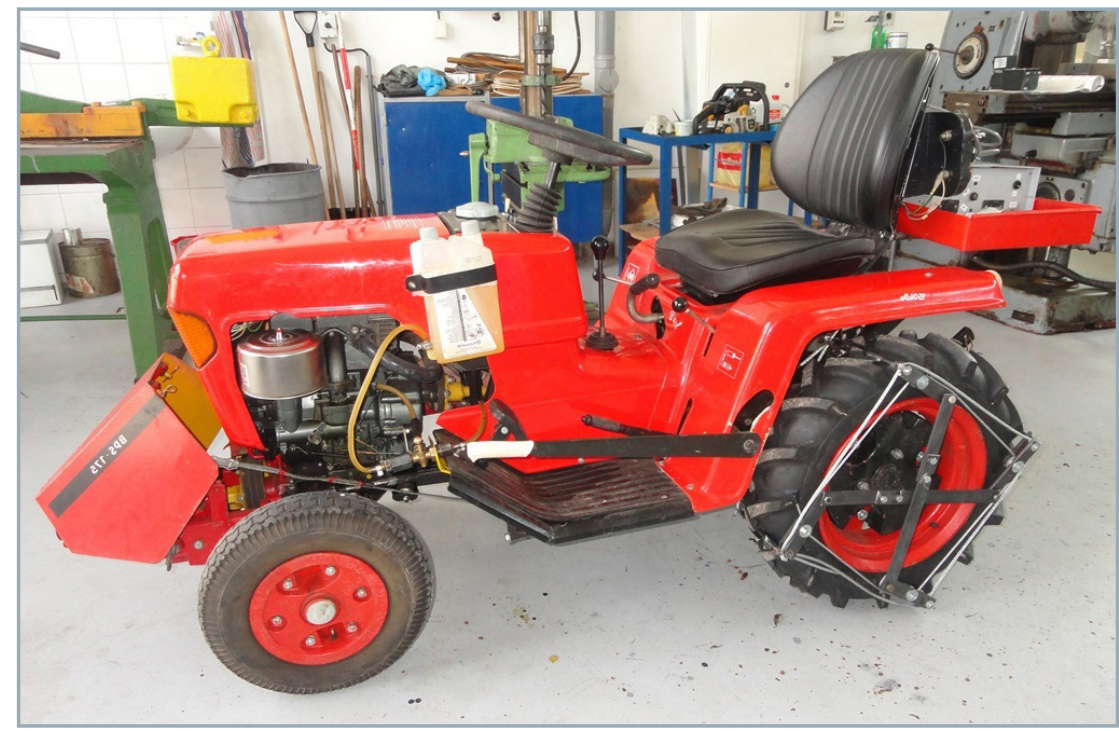

Fig. 1 The tractor type Mini 070 equipped with prototypes of driving wheels

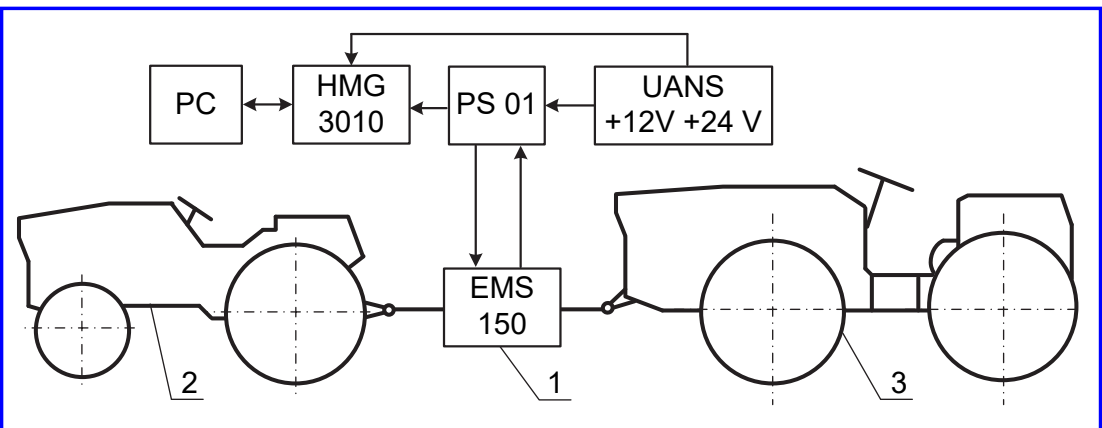

Fig. 2 System for measurement of tractor drawbar pulls

1 - force sensor EMS 150; 2 - tractor type Mini 070 equipped with different wheel types; 3 - loading tractor of type TZ-4K-14; HMG 3010 - digital portable recording device; UANS - universal battery source, PC - personal computer; PS 01 - junction box

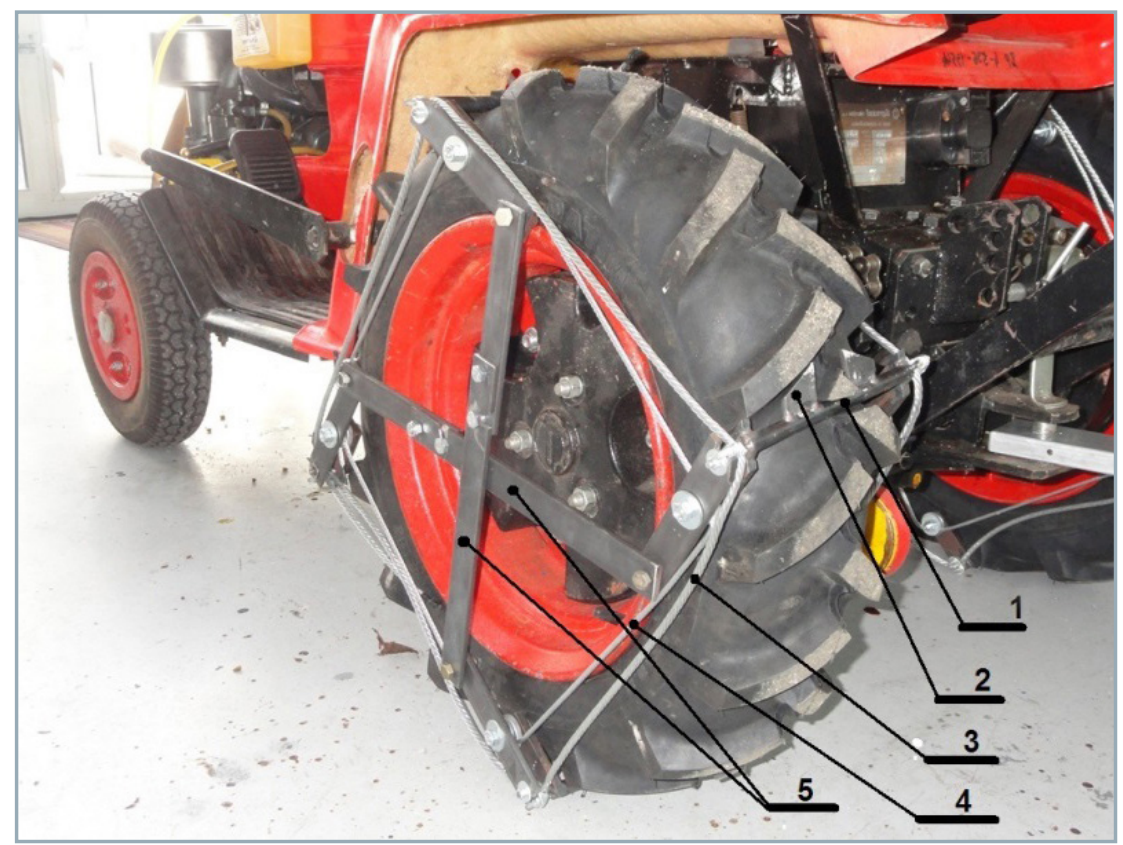

Fig. 3 Prototypes of driving wheels

1 - cross-beam; 2 - spike; 3 - carrying wire rope; 4 - control wire rope; 5 - locking levers setting tilted/reclined position was selected instead of two-wheel drive type in order to prevent a wheel slip of the loading tractor at high load. This is a way how to make a constant load during the passing of the tractor Mini 070 with different driving wheels on the grass plot. The loading tractor is equipped with a sufficient wheel diameter, avoiding the wheel blocking during the loading process due to a high rolling resistance typical for wheels with smaller diameter on nonroad surfaces. The weight of the loading tractor had a sufficient reserve for providing the load to the tractor Mini 070 also at higher load level. Constant load was achieved by the turning of engine (activated decompressor) together with transmissions of loading tractor at different gears engaged. Three different loading levels were selected for the experiment: low load (no gear of loading tractor engaged); medium load (fourth gear of loading tractor engaged); high load (third gear of loading tractor engaged).

The force sensor was connected between the loading tractor TZ-4K-14 (Agrozet, Czech Republic) and the tractor Mini 070 through a chain. Portable recording unit HMG 3010 (Hydac GmbH, Germany) was used for recording signals from the force sensor.

\section{Prototypes of driving wheels}

The prototypes of driving wheels were used with the tyres Mitas 6.5/75-14 TS -02 (Mitas a.s., Czech Republic) and consisted of four segments (Fig. 3) connected together by carrying wire rope [3] and operated by control wire rope [4].

The control wire [4] provides spikes tipping from the tyre body and mutual holding of individual components in the same position. Spikes are tilted for avoiding the need for removal when moving on the road and reduction of health risks for operator (Drlička and Kročko, 2005). Spikes [1] are tilted by rotation to tangential position so they do not extend beyond the tyre body; they automatically eject due to tractor drive wheel slip when the mechanism [5] is locked-off. It is necessary to lock the spikes [1] in tilted position by means of levers [5] in order to prevent spikes to recline during the generation of drawbar pull back in reverse motion. Locked transport position suitable for movement on paved roads, using 


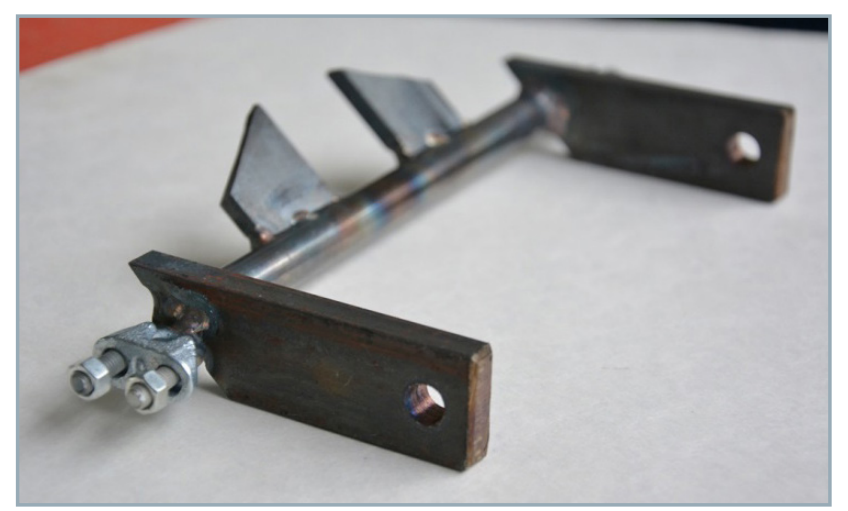

Fig. 4 Detail of a single spike component

levers [5] for holding reclined spikes [1], is depicted in Fig. 3. A single spike component is shown in Fig. 4.

Proposed prototypes of tractor driving wheels were designed and manufactured from common profiles made of standard structural steel grade S355JR in laboratories of the Faculty of Engineering of SUA in Nitra. Spikes made of higher quality steel could improve the durability of prototypes under operational conditions (Drlička et al., 2013).

\section{Measurement and calculation of drive wheel slip}

Supportive measurement of tractor slip moving on elastic base was performed according to common methodology. The first measuring sector is staked on the soil using measuring tape and marked by two rods at start and finish. Tractor movement time was measured using stopwatch, starting when the front part of the tractor passed the starting rods and ending when the same tractor part passed the finishing rods. Tractor wheel slip was measured by means of a line drawn on wheel, which served for counting of number of revolves of drive wheel within the measuring sector. Actual tractor speed was calculated according to the following formula:

$$
v=\frac{s}{t}, \mathrm{~m} \cdot \mathrm{s}^{-1}
$$

where:

$s \quad$ - staked sector with a length of $30 \mathrm{~m}$

$t \quad$ - time necessary for passing the sector, $s$

Theoretical speed $\left(v_{t}\right)$ was calculated according to the following formula:

$$
v_{t}=\frac{2 \pi \cdot r_{d} \cdot n_{m}}{i_{c}}, m \cdot s s^{-1}
$$

where:

$$
\begin{aligned}
& r_{d} \quad-\text { dynamic radius of drive tyre, } \mathrm{m} \\
& n_{m} \quad-\text { nominal engine speed, } \mathrm{s}^{-1} \\
& i_{c} \quad-\text { gear ratio }
\end{aligned}
$$

The slip of the tractor drive wheels was calculated according to the following formula:

$$
\delta=\left(1-\frac{n_{t}}{n_{s k}}\right) \cdot 100, \%
$$

where:

$n_{t} \quad$ - theoretical speed of wheel with no load in the measuring sector, $\mathrm{s}^{-1}$

$n_{\text {sk }}$ - actual wheel speed with load in the same measuring sector, $\mathrm{s}^{-1}$

The slip of drive wheels can be verified according to the following formula:

$$
\delta=\left(1-\frac{v}{v_{t}}\right) \cdot 100, \%
$$

where:

$\mathrm{v} \quad$ - actual speed, $\mathrm{m} \cdot \mathrm{s}^{-1}$

$v_{t} \quad$ - theoretic speed, $\mathrm{m} \cdot \mathrm{s}^{-1}$

\section{Calculation of drawbar power}

Drawbar power is determined by the drawbar pull and motion speed of tractor. The drawbar characteristics of tractor determine the tractor drawbar capacity defined by its drawbar pull $F_{t}$ at particular motion speed, specifying the tractor drawbar power $P_{t}$. Tractor drawbar power significantly determines the driving mechanism slip $\delta$, especially on unpaved supports (Semetko et al., 2003; Semetko et al., 2004). Slip values are thus necessary for specification of drawbar parameters.

Tractor drawbar power can be calculated according to:

$$
P_{t}=F_{t} \cdot v, \quad W
$$

where:

$F_{t} \quad-$ drawbar pull, $\mathrm{N}$

$\mathrm{v} \quad-$ actual speed, $\mathrm{m} \cdot \mathrm{s}^{-1}$

\section{Measurement procedure of speed and slip of tractor Mini $\mathbf{0 7 0}$}

Drawbar pull measurements were carried out in accordance with STN ISO 789-9. The speed and slip measuring procedure consisted of the following steps:

- measuring sector $30 \mathrm{~m}$ was designated on grass using two rods at the sector start and finish;

- white mark was drawn on the tractor Mini 070 wheel perimeter for counting of the number of wheel revolves;

- in the first measurement, the tractor with no load passes the whole sector, the number of wheel revolves is counted and time measured;

- the tractor returned to the start of measuring sector;

- the tractor TZ-4K-14 (no gear engaged) was attached to the tractor via drawbar pull sensor;

- the heater plug from the engine head of the tractor TZ-4K14 was removed in order to provide constant drawbar pull with the third and fourth gear engaged and stopped engine;

- the system started in sufficient distance before the sector start;

- the stopwatch was started when the tractor front passed the starting rods, the drawbar pull measurement of Hydac 3010 and counting of the drive wheel rotations were started;

- the stopwatch and counting of drive wheel rotations were stopped when the tractor front part passed the finish rods; 
- values were recorded in a table and measurement with the tractor TZ-4K-14 attached, with fourth and then third gear engaged to cover all possibilities was repeated;

- the first and second gears were set on the tractor Mini with prototypes of driving wheels and common tyres during the measurement according to the aforementioned methodology.

\section{Results and discussion}

Measurements were performed in March 2016 with average volume soil humidity $33.2 \%$ and soil volume weight $1.66 \mathrm{~g} \cdot \mathrm{cm}^{-3}$; they were carried out on the grass plane surface at sunny weather in Slovak Agricultural Museum in Nitra. The area for measurement was approximately $0.5 \mathrm{ha}$. The measuring sector limited by rods had a rectangular shape with dimensions of $30 \times 25 \mathrm{~m}$.

Achieved results (Tables 1 and 2) were divided for evaluation depending on which gear was engaged in the tractor Mini 070 during testing.

Variances were observed in drawbar pull when using common and spike tyre, as it is shown in Fig. 5. These differences are caused by higher motion speed achieved by the tractor with prototypes of driving wheels facilitating higher engine speed of the tractor TZ-4K-14, resulting in recorded higher drawbar pull and higher mechanical resistance. Similar variances were observed during measurements with the second gear engaged (Fig. 6), with differences even more significant due to higher motion speed.

Fig. 7 provides the best comparison of effectiveness of driving force transmission onto support. An improvement of driving force when prototypes with tilting spikes at the first gear were used was observed based on dependency of slip on drawbar performance. This improvement can be characterized by higher drawbar performance achieved by prototypes, keeping linear dependency of slip on drawbar from $850 \mathrm{~W}$ up to $1,000 \mathrm{~W}$, with the slip growing linearly for both wheel types below the power $850 \mathrm{~W}$, while this dependency changes from linear to parabolic already at 850 W and slip rises sharply.

Even better improvement of driving force onto support transmission at the second gear when using prototypes with tilted spikes can be observed in slip on drawbar pull dependency results (Fig. 7). This improvement can be

Table 1 Measured values of the tractor with common tyres

\begin{tabular}{|c|c|c|c|c|c|c|c|c|}
\hline $\begin{array}{l}\text { Gear used in } \\
\text { pulled tractor } \\
\text { (load) }\end{array}$ & $\begin{array}{l}\text { Travel } \\
\text { time (s) }\end{array}$ & $\begin{array}{l}\text { Speed } \\
\left(\mathrm{m} \cdot \mathrm{s}^{-1}\right)\end{array}$ & $\begin{array}{c}\text { Speed } \\
\left(\mathbf{k m} \cdot \mathbf{h}^{-1}\right)\end{array}$ & $\begin{array}{c}\text { Theoretical } \\
\text { wheel } \\
\text { revolution }\end{array}$ & $\begin{array}{l}\text { Actual } \\
\text { wheel } \\
\text { revolution }\end{array}$ & Slip (\%) & $\begin{array}{l}\text { Average } \\
\text { drawbar } \\
\text { pull (N) }\end{array}$ & $\begin{array}{c}\text { Drawbar } \\
\text { power (W) }\end{array}$ \\
\hline \multicolumn{9}{|c|}{ Tractor parameters at the first gear } \\
\hline No load & 71 & 0.42 & 1.52 & \multirow{4}{*}{16.46} & 16.5 & & & \\
\hline No gear & 78 & 0.38 & 1.38 & & 16.9 & 5.33 & $1,174.88$ & 451.88 \\
\hline 4 & 83 & 0.36 & 1.30 & & 17.3 & 7.51 & $2,336.12$ & 844.38 \\
\hline 3 & 110 & 0.27 & 0.98 & & 23.0 & 30.43 & $2,986.50$ & 814.50 \\
\hline \multicolumn{9}{|c|}{ Tractor parameters at the second gear } \\
\hline No load & 39 & 0.77 & 2.77 & \multirow{4}{*}{16.46} & 16.6 & & & \\
\hline No gear & 45 & 0.67 & 2.40 & & 17.6 & 9.09 & 924.53 & 616.36 \\
\hline 4 & 58 & 0.52 & 1.86 & & 20.3 & 21.18 & $2,765.98$ & $1,430.68$ \\
\hline 3 & 98 & 0.31 & 1.10 & & 25.0 & 36.00 & $3,467.78$ & $1,061.57$ \\
\hline
\end{tabular}

Table 2 Measured values of the tractor with prototypes of driving wheels

\begin{tabular}{|c|c|c|c|c|c|c|c|c|}
\hline $\begin{array}{l}\text { Gear used in } \\
\text { pulled tractor } \\
\text { (load) }\end{array}$ & $\begin{array}{l}\text { Travel time } \\
\text { (s) }\end{array}$ & $\begin{array}{l}\text { Speed } \\
\left(\mathrm{m} \cdot \mathrm{s}^{-1}\right)\end{array}$ & $\begin{array}{c}\text { Speed } \\
\left(\mathbf{k m} \cdot \mathrm{h}^{-1}\right)\end{array}$ & $\begin{array}{l}\text { Theoretical } \\
\text { wheel } \\
\text { revolution }\end{array}$ & $\begin{array}{c}\text { Actual } \\
\text { wheel } \\
\text { revolution }\end{array}$ & Slip (\%) & $\begin{array}{c}\text { Average } \\
\text { drawbar } \\
\text { pull (N) }\end{array}$ & $\begin{array}{c}\text { Drawbar } \\
\text { power (W) }\end{array}$ \\
\hline \multicolumn{9}{|c|}{ Tractor parameters at the first gear } \\
\hline No load & 71 & 0.42 & 1.52 & \multirow{4}{*}{16.46} & 16.6 & & & \\
\hline No gear & 74 & 0.41 & 1.46 & & 16.8 & 4.76 & $1,094.60$ & 443.76 \\
\hline 4 & 78 & 0.38 & 1.38 & & 18.2 & 12.09 & $2,542.86$ & 978.02 \\
\hline 3 & 103 & 0.29 & 1.05 & & 23.3 & 31.33 & $3,210.57$ & 935.12 \\
\hline \multicolumn{9}{|c|}{ Tractor parameters at the second gear } \\
\hline No load & 39 & 0.77 & 2.77 & \multirow{4}{*}{16.46} & 16.6 & & & \\
\hline No gear & 41 & 0.73 & 2.63 & & 18 & 11.11 & 712.04 & 521 \\
\hline 4 & 49 & 0.61 & 2.2 & & 20.5 & 21.95 & $2,875.23$ & $1,760.34$ \\
\hline 3 & 57 & 0.53 & 1.89 & & 22.3 & 28.25 & $3,267.75$ & $1,719.87$ \\
\hline
\end{tabular}




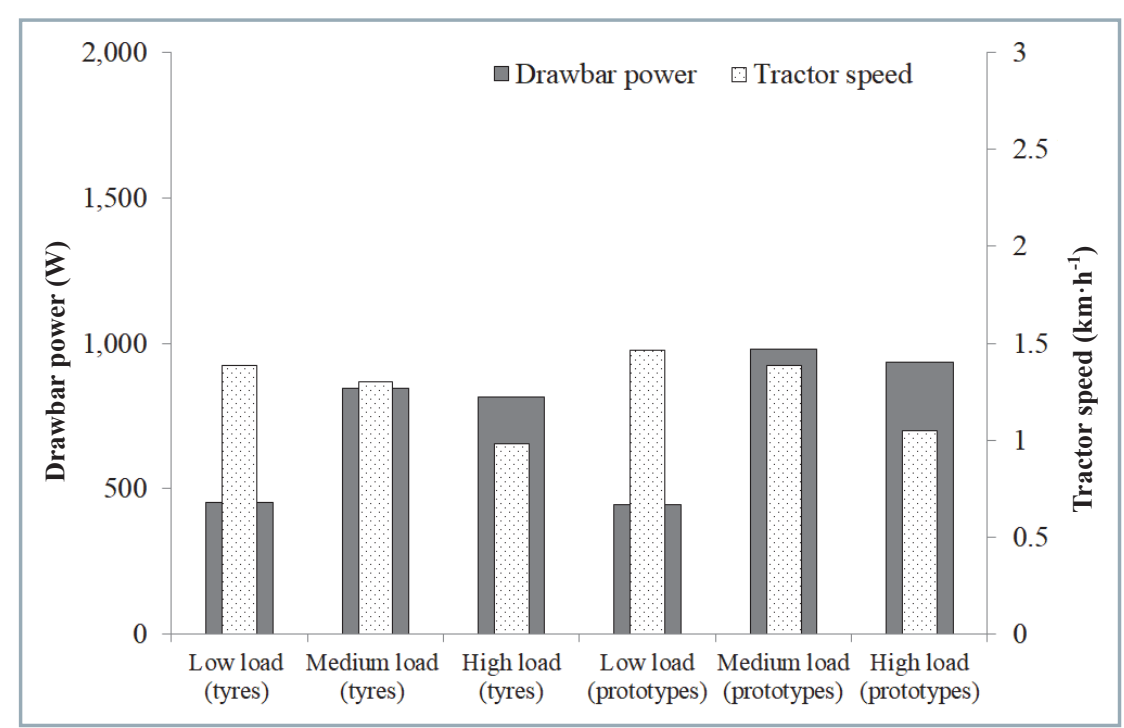

Fig. 5 Comparison of speed and drawbar power at the first gear

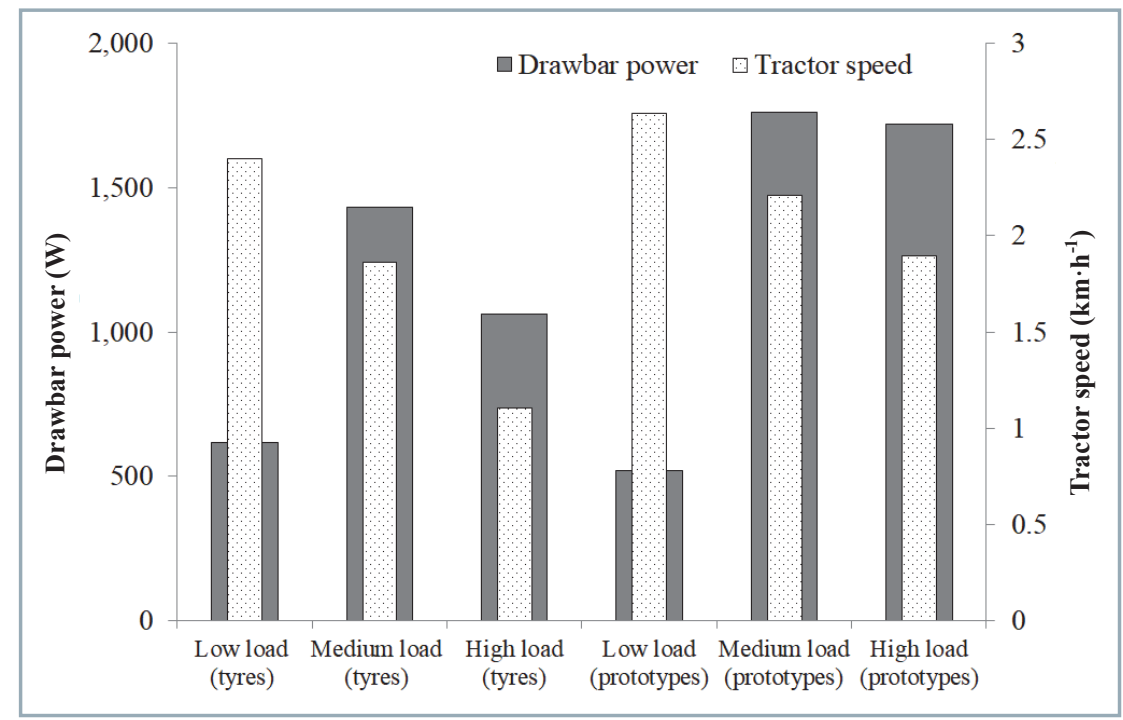

Fig. 6 Comparison of speed and drawbar power at the second gear

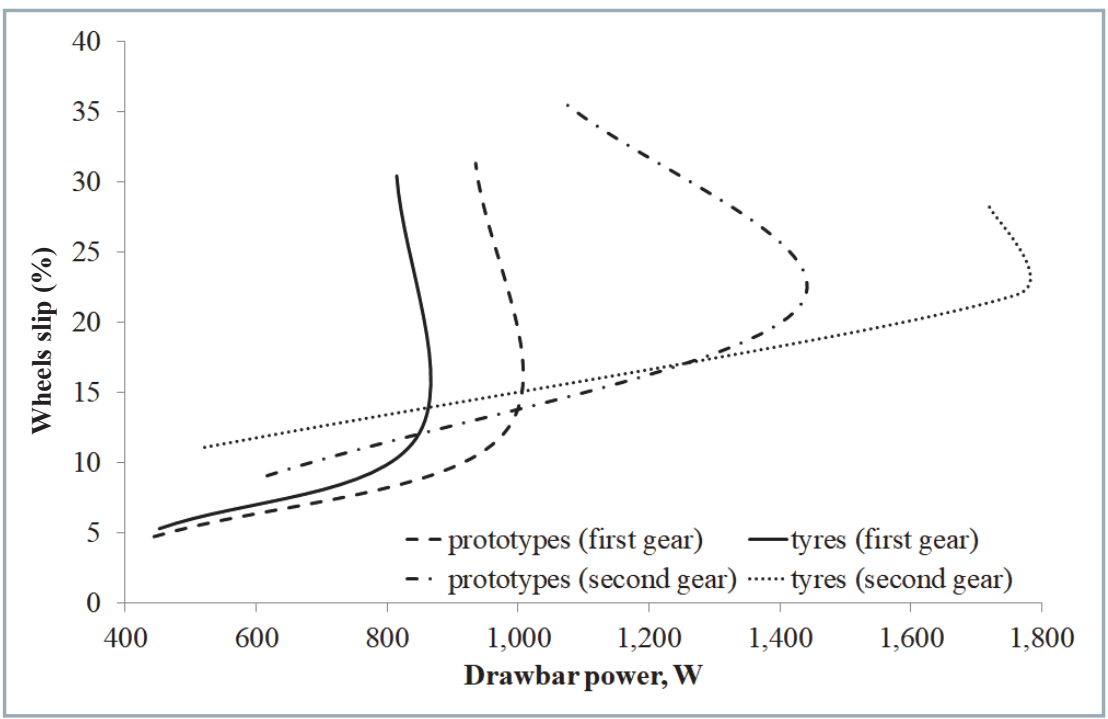

Fig. 7 Comparison of slip of both drive wheel types at the first and second gears characterized as linear rise of slip with drawbar performance growth in case of both types of drive wheels up to certain value (Kielbasa and Korenko, 2006). Prototypes generate higher drawbar performance from approximately $1,430 \mathrm{~W}$ and keep the linear dependency of slip on drawbar performance towards up to $1,760 \mathrm{~W}$, as apparent from Fig. 7. Common tyres change the dependency from linear to parabolic at $1,430 \mathrm{~W}$, and slip rises sharply.

In their work, Battiato and Diserens (2013) present that although the tractor developed a higher drawbar pull when tyre inflation pressure was decreased and wheel load was increased, only the decrease in tyre pressure produced improvements in terms of drag coefficient, tractive efficiency, power delivery efficiency, and specific fuel consumption, while the only significant benefit due to the increase in wheel load was a reduction in the specific fuel consumption at a tyre pressure of $160 \mathrm{kPa}$ and a slip of under 15\%. GeeClough et al. (1977) present the traction performance of tractor depending on tyre inflation as well. Comparing these results with those obtained in our study, we improved the tractor performance using the prototypes of driving wheels. In this case, wheel load and tyre inflation did not change because, as mentioned before, they lower the slip in comparison to tyres without any modification.

Curves showing the dependence of drawbar power, tractive efficiency and specific fuel consumption on dynamic traction ratio and slip are presented in a work of Jenane et al. (1996). These curves are used forillustration of increases in fuel consumption resulting from the tractor not utilizing its maximum traction performance. Depending on the soil surface, the minimum specific fuel consumption was achieved at values of slip varying between $10 \%$ and $30 \%$. The operation of tractor at its maximum tractive performance due to lower tyre slip was achieved using the presented prototypes.

Traction performance and fuel efficiency tests were presented by Turner et al. (1997), providing the comparison of two different rubber belt tractors with two similar mechanical front wheel drive tractors equipped with radial tyres. Three different test 
methods were used on both tilled and untilled clay loam soil. Optimized systems showed only small differences in overall performance and efficiency in good traction conditions. This was also the factor in which both types of vehicles showed their best power delivery performance. Belted tractors showed their greatest benefit when operated at vehicle traction ratios (VTRs) of 0.6 or higher or in soft or loose soil conditions. In comparison with the test presented by Turner et al. (1997), our solution can improve the traction performance under good traction conditions (grass plot) as well.

The prototypes of driving wheels are equipped with spikes built into tyre body unlike various types of lugged wheels - spikes will be hidden without need for removal when moving on paved roads. This solution can be applied to tyres suitable for cutting with higher tread cap rubber layer over the tyre steel belts.

\section{Conclusion}

The prototypes of driving wheels were designed in basic version with four spike segments for function tests. The number of spike segments will be doubled in future research while preserving the same control system. The design was intentionally tested at relatively high soil humidity (33.2\%) in order to emphasise the difference in the drawbar properties of tyre and spike tyre. The prototypes will be implemented in an off-road car tyre in the future for their comparison in long-lasting tests under various conditions such as wood road cruise or under winter conditions. The prototypes can be easily removed in case of exceeding the wear limit and the tyre can be utilized until its total loss of the tread.

The prototypes were tested for the first time in this version and we assume that drawbar performance improvement will be more significant on surfaces such as dry soil covered by manure, or frozen surfaces. The prototypes were developed on the basis of previous research of improvements in drive wheel drawbar pull transmission on support, where lugged wheels on two-wheel tractor were the best solution.

On the basis of improvement in achieved tractor tyre drawbar properties, it can be concluded that the prototypes favourably influence the slip of drive wheels, as well as they improve the efficiency of driving force transmission onto support at relative higher soil moisture by $33.2 \%$ when compared with common tyres.

\section{Acknowledgement}

Supported by the Ministry of Education of the Slovak Republic, project VEGA 1/0155/18.

\section{References}

ABRAHÁM, R. - MAJDAN, R. - DRLIČKA, R. 2015. Possibilities of improving the wheel tractor drive force transmission to soil. In Research in Agricultural Engineering, vol. 61, special issue, pp. 37-42. BATTIATO, A. - DISEREN, E. 2013. Influence of tyre inflation pressure and wheel load on the traction performance of a $65 \mathrm{~kW}$ MFWD tractor on a cohesive soil. In Journal of Agricultural Science, vol. 5, no. 8, pp. 197-215.

DRLIČKA, R. - KROČKO, V. 2005. Comparison of the accident rate development in agriculture and other fields of national economy. In Bezpečnost' - kvalita - spol'ahlivost', Košice : Technical University of Košice. ISBN 80-8073-258-2.
DRLIČKA, R. - ŽARNOVSKÝ, J. - MIKUŠ, R. - KOVÁČ, I. - KORENKO, M. 2013 Hard machining of agricultural machines parts. In Research in Agricultural Engineering, vol. 59, special issue, pp. 42-48.

DUIKER, S. 2004. Avoiding soil compaction. Retrieved from: https:// extension.psu.edu/ avoiding-soil-compaction.

GEE-CLOUGH, D. - McALLISTER, M. - EVERNDEN, D. W. 1977. Tractive performance of tractor drive tyres. In Journal of Agricultural Engineering Research, vol. 22, no. 4 pp. 385-395.

HUJO, L. - KOSIBA, J. - JABLONICKÝ, J. - DRABANT, Š. 2012. Theoretical design of a laboratory test device for the testing of tractor hydraulics. In Technics in Agrisector Technologies 2012, pp. 68-73. ISSN 1335-2555.

JENANE, C. - BASHFORD, L. L. - MONROE, G. 1996. Reduction of fuel consumption through improved tractive performance. In Journal of Agricultural Engineering Research, vol. 64, no. 2, pp. 131-138.

KIELBASA, P. - KORENKO, M. 2006. Influence of machine working resistance on slippage rate of driving wheels of tractor. In Acta Technologica Agriculturae, vol. 9, pp. 44-47.

KOSIBA, J. - DRABANT, Š. - UHRINOVÁ, D. - BOHÁT, M. - HUJO, L.. 2010. Noise measurement of agriculture machineries. In Acta Technologica Agriculturae, vol. 13, no. 3, pp. 65-68.

MALÝ, V. - TÓTH, F. - MAREČEK, J. - KRČÁLOVÁ, E. 2015. Laboratory test of the soil compaction. In Acta Universitatis Agriculturae et Silviculturae Mendelianae Brunensis, vol. 63, no. 1, pp. 77-85.

MALÝ, V. - KUČERA, M. 2014. Determination of mechanical properties of soil under laboratory conditions. In Research in Agricultural Engineering, vol. 60, special issue, pp. 66-69.

MÜLLEROVÁ, D. - JABLONICKÝ, J. - HUJO, L. - TKÁČ, Z. - KUČERA, M. - KOSIBA, J. 2012. Measurement of operating parameters and emissions of tractor with diesel oil and biofuel. In TEAM 2012. Slavonski Brod : University of Applied Sciences of Slavonski Brod, pp. 299-302. ISSN 1847-9065.

RATAJ, V. - GALAMBOŠOVÁ, J. - MACÁK, M. 2009. Experience in application of CTF system in Slovak Republic. In GPS autopiloty v zemědělství. Prague : Czech University of Life Science in Prague, pp. 34-38. ISBN 978-80-213-1993-6.

RATAJ, V. - MACÁK, M. - BARÁT. M - GALAMBOŠOVÁ, J. 2016. Soil compaction and soil moisture content in extreme climate conditions. In International Conference on Trends in Agricultural Engineering. Prague : Czech University of Life Sciences, pp. 528536. ISBN 978-80-213-2682-8.

SEMETKO, J. - JANOŠKO, I. - PERNIS, P. 2004. Determination of power of multidrive vehicles. In Acta Technologica Agriculturae, vol. 7, no. 1, pp. 20-23.

SEMETKO, J. - Priecel, J. - JANOŠKO, I. 2003. Theoretical principles of slipping speed estimation. In Acta Technologica Agriculturae, vol. 6, no. 4, pp. 96-98.

STN ISO 789-9: 1993. Power test for drawbar. Slovak Office of Standards, Metrology and Testing.

TULÍK, J. - KOSIBA, J. - HUJO, L’. - JABLONICKÝ, J. - ŠINSKÝ, V. 2013. The durability of a tractor gear-hydraulic circuit. In Trends in Agricultural Engineering 2013, Prague : Czech University of Life Sciences Prague, pp. 617-621. ISBN 978-80-123-2388-9.

TURNER, R. - SHELL, L. - ZOZ, F. 1997. Field performance of rubber belted and MFWD tractors in Southern Alberta soils. In SAE Technical Paper - Belt and Tire Traction in Agricultural Vehicles, SP1291, pp. 75-85.

UHRINOVÁ, D. - JABLONICKÝ, J. - HUJO, L. - KOSIBA, J. 2011 a. Detection of emission in combustion engines' exhaust. In Machines, Technologies, Materials, vol. 5, no. 4, pp. 53-56.

UHRINOVÁ, D. - MACKELLAR, L. - SCHIESS, I. - JABLONICKÝ, J. - PRÍSTAVKA, M. 2011b. Operating parameters and emission evaluation of tractors running on diesel oil and biofuel. In Research in Agricultural Engineering, vol. 57, special issue, pp. 35-42. 